\title{
Co(III) and Ni(II) Complexes Containing Bioactive Ligands: Synthesis, DNA Binding, and Photocleavage Studies
}

\author{
M. C. Prabhakara, ${ }^{1}$ B. Basavaraju, ${ }^{2}$ and H. S. Bhojya Naik ${ }^{1}$ \\ ${ }^{1}$ Department of PG Studies and Research in Industrial Chemistry, School of Chemical Sciences, Kuvempu University, \\ Shankaraghatta, Shimoga, Karnataka 577 451, India \\ ${ }^{2}$ Department of Biotechnology, GM Institute of Technology, Davanagere, Karnataka 577 006, India
}

Received 8 August 2006; Revised 24 November 2006; Accepted 27 November 2006

Recommended by Giovanni Natile

\begin{abstract}
DNA binding and photocleavage characteristics of a series of mixed ligand complexes of the type $\left[\mathrm{M}(\mathrm{bpy})_{2} \mathrm{qbdp}\left(\mathrm{PF}_{6}\right)_{\mathrm{n}} \cdot \mathrm{xH}_{2} \mathrm{O}\right.$ (where $\mathrm{M}=\mathrm{Co}(\mathrm{III})$ or $\mathrm{Ni}(\mathrm{II})$, bpy $=2.2^{\prime}$-bipryidine, $\mathrm{qbdp}=$ Quinolino[3,2-b]benzodiazepine, $\mathrm{n}=3$ or 2 and $\mathrm{x}=5$ or 2 ) have been investigated. The DNA binding property of the complexes with calf thymus DNA has been investigated by using absorption spectra, viscosity measurements, as well as thermal denaturation studies. Intrinsic binding constant $\left(K_{\mathrm{b}}\right)$ has been estimated under similar set of experimental conditions. Absorption spectral studies indicate that the $\mathrm{Co}$ (III) and Ni(II) complexes intercalate between the base pairs of the CT-DNA tightly with intrinsic DNA binding constant of $1.3 \times 10^{6}$ and $3.1 \times 10^{5} \mathrm{M}^{-1}$ in Tris- $\mathrm{HCl}$ buffer containing $50 \mathrm{mM} \mathrm{NaCl}$, respectively. The proposed DNA binding mode supports the large enhancement in the relative viscosity of DNA on binding to quinolo[3,2-b]benzodiazepine. The oxidative as well as photo-induced cleavage reactions were monitered by gel electrophoresis for both complexes. The photocleavage experiments showed that the cobalt(III) complex can cleave pUC19 DNA effectively in the absence of external additives as an effective inorganic nuclease.
\end{abstract}

Copyright (C) 2007 M. C. Prabhakara et al. This is an open access article distributed under the Creative Commons Attribution License, which permits unrestricted use, distribution, and reproduction in any medium, provided the original work is properly cited.

\section{INTRODUCTION}

The interaction and reaction of metal complexes with DNA have long been the subject of intense investigation in relation to the development of new reagents for biotechnology and medicine. Studies of small molecules, which react at specific sites along a DNA strand as reactive models for protein-nucleic acid interactions, provide routes towards rational drug design as well as means to develop sensitive chemical probes for DNA. A number of metal complexes have been used as probes of DNA structure in solution, as agents for mediation of strand scission of duplex DNA and as chemotherapeutic agents [1-7]. In this regard, mixed-ligand metal complexes have been found to be particularly useful because of their potential to bind DNA via a multitude of interactions and to cleave the duplex by virtue of their intrinsic chemical, electrochemical, and photochemical reactivities [8-15]. Prominent among the various mixedligand metal complexes employed so far in studies with DNA are those metallointercalators which incorporate either $2.2^{\prime}$-bipyridine(bpy)/1.10 phenanthroline or a modified bipyridine/phenanthroline moiety or aromatic heterocyclic ring as a ligand. A singular advantage in using these metallointercalators for such studies is that the ligands or the metal ion in them can be varied in an easily controlled manner to facilitate individual applications [16-18]. Although DNA interactions of number of mixed ligand complexes have previously appeared in the literature, still there is scope to design and study small molecules containing mixed ligand with the same or different metal ions as new chemical nucleases.

In continuation of our work on studies of nuclease activity of mixed-ligand complexes, we wish to explore the binding and oxidative as well as photocleavage activities of mixed ligand complexes of $\mathrm{Co}(\mathrm{III})$ and $\mathrm{Ni}$ (II) containing bipyridine and condensed quinoline derivative ligand.

\section{EXPERIMENTAL}

All reagents and solvents were of AR grade, purchased commercially. All the solvents were purified and used. $O$ Phenylenediammine, $\mathrm{CoCl}_{2} \cdot 6 \mathrm{H}_{2} \mathrm{O}, \mathrm{NiCl}_{2} \cdot 6 \mathrm{H}_{2} \mathrm{O}$ and $2.2^{\prime}-$ bipyridine, ammonium hexaflurophosphate $\left(\mathrm{NH}_{4} \mathrm{PF}_{6}\right)$, and Tris- $\mathrm{HCl}$ buffer were purchased from Qualigens (Mumbai, India). Calf thymus DNA (CT-DNA) and pUC19 DNA were 


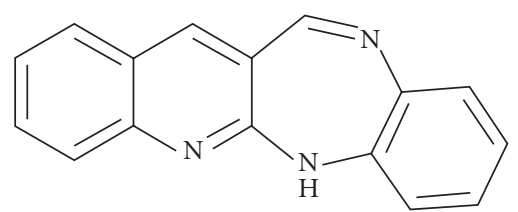

FIGURE 1: Quinolino[3,2-b]benzodiazepine(qbdp).

purchased from Bangalore Gene, Bangalore, India. Tris$\mathrm{HCl}$ buffer $(5 \mathrm{mM}$ Tris- $\mathrm{HCl}, 50 \mathrm{mM} \mathrm{NaCl}, \mathrm{pH}-7.2$, Tris = Tris(hydroxymethyl) amino methane) solution was prepared using deionised double distilled water.

\subsection{Synthesis of quinolino[3,2-b]benzo- diazepine(qbdp)}

2-Chloro-3-quinolinecarbaldehyde $(0.958 \mathrm{~g}, 5 \mathrm{mmol})$ dissolved in small amount of acetic acid was taken in a $100 \mathrm{~mL}$ borosil beaker. $o$-Phenylenediammine $(0.541 \mathrm{~g}, 5 \mathrm{mmol})$ and a pinch of potassium iodide were then added. The whole mixture was made into slurry and was irradiated by placing the beaker in a microwave oven for about 10 minutes. The completion of the reaction was monitored by TLC. The product obtained was poured into ice-cold water, the solid separated was filtered, dried, recrystallized, and its physical constants were measured (see Figure 1).

Analysis: calculated for $\mathrm{C}_{16} \mathrm{H}_{11} \mathrm{~N}_{3} ; \mathrm{C}, 78.35 ; \mathrm{H}, 4.52 ; \mathrm{N}$, 17.13\%; found: C, 78.52; H, 4.76; N, 17.35\%; IR (KBr, cm $\left.{ }^{-1}\right)$ : $3330(\mathrm{~N}-\mathrm{H}) ; 1576(\mathrm{C}=\mathrm{C}) ; 1658(\mathrm{C}=\mathrm{N}) ; 2924(\mathrm{C}-\mathrm{H}$, aromatic); ${ }^{1} \mathrm{H}$ NMR (DMSO-d $\left.{ }_{6}\right): \delta 10.65(\mathrm{~s}, 1 \mathrm{H}, \mathrm{NH}) ; 8.4(\mathrm{~s}$, $1 \mathrm{H}, \mathrm{H}-\mathrm{C}=\mathrm{N}) ; 7.2-7.8$ (m, 9H, Ar-H); MS: $m / z$ 248.5.

\subsection{Synthesis of metal complexes}

\subsubsection{Synthesis of $\mathrm{CO}(\mathrm{III})$ and $\mathrm{Ni}(\mathrm{II})$ complexes}

The complexes $\left[\mathrm{Co}(\mathrm{bpy})_{2} \mathrm{Cl}_{2}\right] \mathrm{Cl} \cdot 3 \mathrm{H}_{2} \mathrm{O}$ and $\left[\mathrm{Ni}(\mathrm{bpy})_{2} \mathrm{Cl}_{2}\right]$ were prepared as reported previously $[19,20]$.

\subsubsection{Synthesis of $\left[\mathrm{Co}(b p y)_{2}(q b d p)\right]\left(\mathrm{PF}_{6}\right)_{3} \cdot 5 \mathrm{H}_{2} \mathrm{O}(1)$}

$\left[\mathrm{Co}(\mathrm{bpy}){ }_{2} \mathrm{Cl}_{2}\right] \mathrm{Cl} \cdot 3 \mathrm{H}_{2} \mathrm{O} \quad(0.53 \mathrm{~g}, \quad 1 \mathrm{mmol})$ and $\mathrm{qbdp}$ $(0.245 \mathrm{~g}, 1 \mathrm{mmol})$ were taken in a solvent mixture containing $20 \mathrm{~mL}$ ethylene glycol and $5 \mathrm{~mL}$ methanol. The resulting mixture was refluxed for 4 hours, allowed to cool, and then filtered. The desired complex was precipitated upon addition of a methanolic solution of $\mathrm{NH}_{4} \mathrm{PF}_{6}$ to the filtrate. The complex was filtered, further and dried under vacuum and recrystallized from an acetone-diethyl ether mixture (see Figure 2). Analysis: yield of complex $0.99 \mathrm{~g}$ (74\%); calculated for $\mathrm{C}_{36} \mathrm{H}_{36} \mathrm{~N}_{7} \mathrm{O}_{5} \mathrm{P}_{3} \mathrm{~F}_{18} \mathrm{Co}$ : C, 71.42; H, 5.24; N, 14.58; Co, 8.76: Found: C, 70.98; H, 5.86; N, 13.84; Co, 9.89. IR, KBr pellets $\left(\mathrm{cm}^{-1}\right): 839,1321,1431,1581,1600 .{ }^{1} \mathrm{H}$ NMR, $\delta \mathrm{ppm}$ (DMSO $\left.\cdot \mathrm{d}_{6}, 200 \mathrm{MHz}\right), \mathrm{ppm}$ (TMS): $9.92(\mathrm{~d}, 2 \mathrm{H}), 9.18(\mathrm{~m}$, $4 \mathrm{H}), 8.92(\mathrm{~d}, 2 \mathrm{H}), 8.60(\mathrm{~d}, 6 \mathrm{H} \mathrm{m}), 8.29(\mathrm{~d}, 2 \mathrm{H}), 8.00(\mathrm{~m}$, $8 \mathrm{H}), 7.70$ (d, $4 \mathrm{H})$; MS: $m / z 658$.

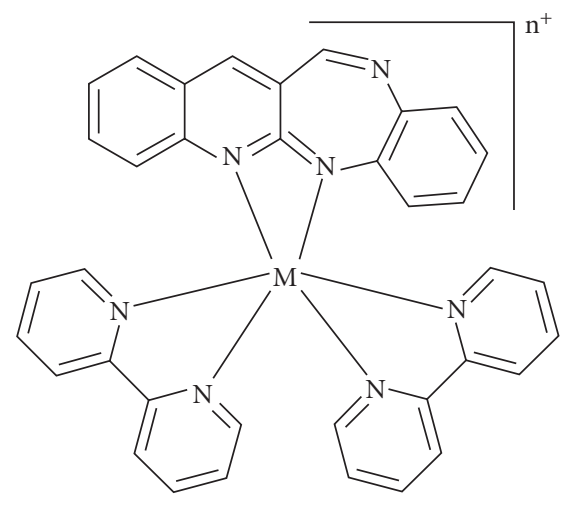

Figure 2: Probable structure of $\left[\mathrm{M}(\mathrm{bpy})_{2} \mathrm{qbdp}\right]$ complex, where $\mathrm{M}=\mathrm{Co}(\mathrm{III})$ or $\mathrm{Ni}(\mathrm{II}), \mathrm{n}=2$ or 3 .

\subsubsection{Synthesis of $\left[\mathrm{Ni}(b p y)_{2}(q b d p)\right]\left(\mathrm{PF}_{6}\right)_{2} \cdot 2 \mathrm{H}_{2} \mathrm{O}$ (2)}

A methanolic solution of $\left[\mathrm{Ni}(\mathrm{bpy})_{2} \mathrm{Cl}_{2}\right](0.44 \mathrm{~g}, 1 \mathrm{mmol})$ was added to a mixture of methanolic solution of qbdp $(0.245 \mathrm{~g}$, $1 \mathrm{mmol})$ and ethylene glycol $(25 \mathrm{~mL})$. The resulting mixture was refluxed for 4 hours, allowed to cool, and then filtered. The crude complex was precipitated upon addition of saturated methanolic solution of $\mathrm{NH}_{4} \mathrm{PF}_{6}$ to the filtrate. The complex was filtered, further and dried under vacuum and recrystallized from an acetone-diethyl ether mixture (see Figure 2). Analysis: yield of complex $0.81 \mathrm{~g}(80 \%)$; calculated for $\mathrm{C}_{36} \mathrm{H}_{30} \mathrm{~N}_{7} \mathrm{O}_{2} \mathrm{P}_{2} \mathrm{~F}_{12} \mathrm{Ni}$ : C, 72.14; $\mathrm{H}, 4.85 ; \mathrm{N}, 12.96 ; \mathrm{Ni}$, 10.56: Found: C, 71.44; H, 5.25; N, 14.58; Ni, 9.73. IR, KBr pellets $\left(\mathrm{cm}^{-1}\right): 839,1333,1420,1587,1605 ;$ MS: $m / z 657$. $\mu_{\text {eff }}=2.76 \pm 0.02$ B.M.

\subsection{Spectral measurements}

Melting points were determined in open capillaries and are uncorrected. Microanalyses (C, H, and N) were performed in Carlo-Erba 1106-model 240 Perkin-Elmer analyzer. The molar conductivities in DMF $\left(10^{-3} \mathrm{M}\right)$ at room temperature were measured using an Equiptronics digital conductivity meter. Magnetic measurements were carried out by the Gouy method at room temperature $\left(28 \pm 2^{\circ} \mathrm{C}\right)$ using $\mathrm{Hg}\left[\mathrm{Co}(\mathrm{SCN})_{4}\right]$ as calibrant. IR spectra were recorded with Shimadzu model FT-IR spectrophotometer by using $\mathrm{KBr}$ pellets. ${ }^{1} \mathrm{H}-\mathrm{NMR}$ spectra were recorded on a Bruker FTNMR spectrometer $(300 \mathrm{MHz})$ at $25^{\circ} \mathrm{C}$ in DMSO with TMS as the internal reference. FAB-MS spectra were recorded with a JEOL SX 102/DA-6000 mass spectrometer/data system. UV visible absorption spectra were recorded using Shimadzu model UV spectrophotometer at room temperature. Viscosity measurements were carried out on semimicro dilution capillary viscometer (Viscomatic Fica MgW) with a thermostated bath D40S at room temperature. Thermal denaturation studies were carried out with a Perkin-Elmer Lambda 35 spectrophotometer.

\subsection{DNA binding and cleavage experiments}

The concentration of CT DNA per nucleotide $[C(p)]$ was measured by using its known extinction coefficient at $260 \mathrm{~nm}$ 
$\left(6600 \mathrm{M}^{-1} \mathrm{~cm}^{-1}\right)[21]$. The absorbance at $260 \mathrm{~nm}\left(\mathrm{~A}_{260}\right)$ and at $280 \mathrm{~nm}\left(\mathrm{~A}_{280}\right)$ for CT DNA was measured to check its purity. The ratio $\mathrm{A}_{260} / \mathrm{A}_{280}$ was found to be 1.84 , indicating that CT DNA was satisfactorily free from protein. Buffer [ $5 \mathrm{mM}$ tris(hydroxymethyl)aminomethane, tris, $\mathrm{pH}$ 7.2, $50 \mathrm{mM} \mathrm{NaCl}$ ] was used for the absorption, viscosity, and thermal denaturation experiments.

Absorption titration experiments were carried out by varying the DNA concentration $(0-100 \mu \mathrm{M})$ and maintaining the metal-complex concentration constant $(30 \mu \mathrm{M})$. Absorption spectra were recorded after each successive addition of DNA and equilibration (approximately 10 minutes). For both the complexes (1) and (2), the observed data were then fit in to (1) to obtain the intrinsic binding constant, $K_{\mathrm{b}}$ [22]:

$$
\frac{[\mathrm{DNA}]}{\left(\varepsilon_{\mathrm{a}}-\varepsilon_{\mathrm{f}}\right)}=\frac{[\mathrm{DNA}]}{\left(\varepsilon_{\mathrm{b}}-\varepsilon_{\mathrm{f}}\right)}+\frac{1}{K_{\mathrm{b}}\left(\varepsilon_{\mathrm{a}}-\varepsilon_{\mathrm{f}}\right)},
$$

where $\varepsilon_{\mathrm{a}}, \varepsilon_{\mathrm{f}}$, and $\varepsilon_{\mathrm{b}}$ are the apparent, free, and bound metalcomplex extinction coefficients at $238 \mathrm{~nm}$ for $\mathrm{Co}$ (III) and $332 \mathrm{~nm}$ for $\mathrm{Ni}(\mathrm{II})$, respectively. A plot of $[\mathrm{DNA}] /\left(\varepsilon_{\mathrm{b}}-\varepsilon_{\mathrm{f}}\right)$ versus [DNA] gave a slope of $1 /\left(\varepsilon_{\mathrm{b}}-\varepsilon_{\mathrm{f}}\right)$ and a $y$ intercept equal to $1 / K_{\mathrm{b}}\left(\varepsilon_{\mathrm{b}}-\varepsilon_{\mathrm{f}}\right)$, where $K_{\mathrm{b}}$ is the ratio of the slope to the $y$ intercept.

Viscosity measurements were carried out using a semimicro dilution capillary viscometer at room temperature. Each experiment was performed three times and an average flow time was calculated. Data were presented as $\left(\eta / \eta_{0}\right)$ versus binding ratio, where $\eta$ is the viscosity of DNA in the presence of complex and $\eta_{0}$ is the viscosity of DNA alone.

Thermal denaturation experiments were carried out by monitoring the absorption of CT DNA $(50 \mu \mathrm{M})$ at $260 \mathrm{~nm}$ at various temperatures in the presence $(5-10 \mu \mathrm{M})$ and the absence of each complex. The melting temperature $\left(T_{\mathrm{m}}\right.$, the temperature at which $50 \%$ of double-stranded DNA becomes single-stranded) and the curve width $\left(\sigma_{T}\right.$, the temperature range between which $10 \%$ and $90 \%$ of the absorption increases occurred) were calculated as reported $[23,24]$.

The extent of cleavage of super coiled (SC) pUC19 DNA $(0.5 \mu \mathrm{L}, 0.5 \mu \mathrm{g})$ to its nicked circular (NC) form was determined by agarose gel electrophoresis in Tris- $\mathrm{HCl}$ buffer (50 mM, pH 7.2) containing $\mathrm{NaCl}(50 \mathrm{mM})$. In the cleavage reactions, the $30 \mu \mathrm{M}$ and $20 \mu \mathrm{M}$ complexes in $18 \mu \mathrm{L}$ buffer were photoirradiated using monochromatic UV or visible light. The samples were then incubated for 1 hour at $37^{\circ} \mathrm{C}$ followed by addition to the loading buffer containing $25 \%$ bromophenolblue, $0.25 \%$ xylene cyanol, $30 \%$ glycerol $(3 \mu \mathrm{L})$, and finally loaded on $0.8 \%$ agarose gel containing $1.0 \mu \mathrm{g} / \mathrm{mL}$ ethidium bromide. Electrophoresis was carried out at $50 \mathrm{~V}$ for 2 hours in Tris-borate EDTA (TBE) buffer. Bands were visualized by UV light and photographed to determine the extent of DNA cleavage from the intensities of the bands using UVItec Gel Documentation System. Due corrections were made for the trace of NC DNA present in the SC DNA sample and for the low affinity of EB binding to SC DNA in comparison to the NC form. The wavelength used for the photo-induced DNA cleavage experiments were $365 \mathrm{~nm}$.
TABLE 1: DNA binding constant and melting-temperature data.

\begin{tabular}{lccc}
\hline Complex & $K_{\mathrm{b}}\left(\mathrm{M}^{-1}\right)$ & $T_{\mathrm{m}}\left({ }^{\circ} \mathrm{C}\right)$ & $\sigma_{\mathrm{T}}\left({ }^{\circ}\right)$ \\
\hline$\left[\mathrm{Co}(\mathrm{bpy})_{2} \mathrm{qbdp}\right]\left(\mathrm{PF}_{6}\right)_{3} \cdot 5 \mathrm{H}_{2} \mathrm{O}$ & $1.3 \times 10^{6}$ & 64 & 25 \\
{$\left[\mathrm{Ni}(\mathrm{bpy})_{2} \mathrm{qbdp}\right]\left(\mathrm{PF}_{6}\right)_{2} \cdot 2 \mathrm{H}_{2} \mathrm{O}$} & $3.1 \times 10^{5}$ & 62 & 21 \\
\hline
\end{tabular}

\section{RESULTS AND DISCUSSION}

\subsection{Characterization of complexes}

The elemental analysis data, IR, ${ }^{1} \mathrm{H}$ NMR, and magnetic moment data of the new complexes are summarized in Section 2 . These data agreed with the theoretical values within the limit of experimental error. These new complexes are insoluble in water, but they are soluble in DMF, DMSO, and in buffer ( $\mathrm{pH}$ 7.2) solution. The conductometric measurement values in DMF indicate their nonelectrolytic nature.

The IR spectra of ligand qbdp show a strong band in the range $3450 \mathrm{~cm}^{-1}$ assigned to $\gamma(\mathrm{NH})$ group. In $\mathrm{Co}(\mathrm{III})$ and $\mathrm{Ni}$ (II) complexes, this band is absent due to by-coordination of nitrogen atom to the metal ion. Besides, the complexes show new bands at $420 \mathrm{~cm}^{-1}$ for $(\mathrm{M}-\mathrm{N})$ bond. In addition, the IR spectrum of the $\mathrm{PF}_{6}$ salt of each complex showed a strong band in the region $837-839 \mathrm{~cm}^{-1}$ ascribable to the counter anion and this band was absent for the corresponding chloride salts [25]. In the ${ }^{1} \mathrm{H}$ NMR spectra of the $\mathrm{Co}$ (III) complex, the peaks due to various protons of bpy and qbdp ligands are seen to be shifted in complexation with corresponding free ligands, suggesting complexation. Unlike the cobalt(III) complexes, which are diamagnetic, nickel(II) complex was found to be paramagnetic with $\mu_{\text {eff }}$ value of $2.77 \pm 0.02$ B.M. as expected for typical $\mathrm{d}^{8}$ system.

\subsection{DNA binding experiments}

\subsubsection{Absorption spectral studies}

In the presence of increasing amounts of CT DNA, both complexes showed hypochromicity and red-shifted charge transfer peak maxima in the absorption spectra. For complexes (1) and (2), the hypochromicity observed in the presence of DNA were 22 and 13\%, and the bathochromic shifts were 2 and $1 \mathrm{~nm}$ (Figures 3 and 4), respectively. The binding constants calculated using (1) are summarized in Table 1. The observed $K_{\mathrm{b}}$ values for $\mathrm{Co}(\mathrm{III})$ and $\mathrm{Ni}(\mathrm{II})$ complexes are equal to classical intercalators [EthBr, $K_{\mathrm{b}}, 1.8 \times 10^{6} \mathrm{M}^{-1}$ in $25 \mathrm{mM}$ Tris- $\mathrm{HCl} / 40 \mathrm{mM} \mathrm{NaCl}$ buffer, $\mathrm{pH}$ 7.9) and partial intercalating metal complexes $\left[\mathrm{Ru}(\mathrm{phen})_{2}(\mathrm{dppz})\right]^{2+}, \mathrm{dppz}=$ dipyrido-[3,2-d: $2^{\prime}, 3^{\prime}$-f]-phenazine, $K_{\mathrm{b}}>10^{6} \mathrm{M}^{-1}$ ] bound to CT-DNA. So it is obvious that the present complexes are involved in interacalative interactions with CT-DNA. These strongest binding affinities exhibited by these complexes are expected on the basis of the additional aromatic nature of new qbdp ligand.

\subsubsection{Viscosity measurements}

Furthermore, the interactions between the complex and DNA were investigated by viscosity measurements. Optical 


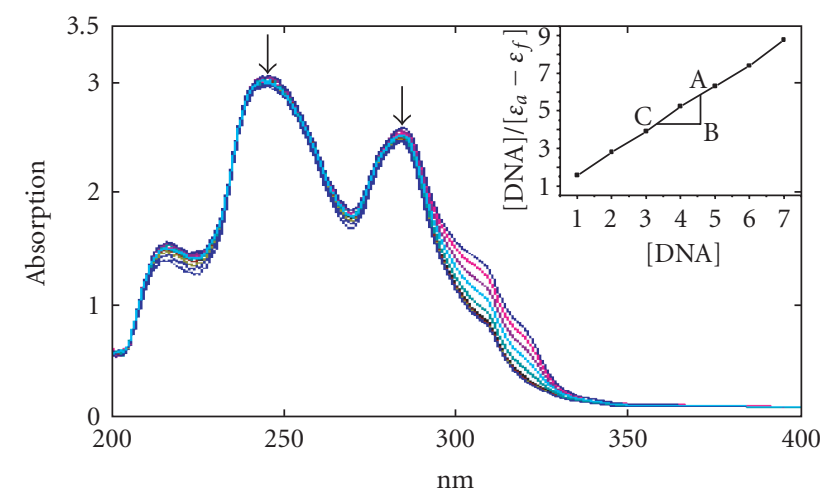

FIgURE 3: Absorption spectra of complex (1) in Tris- $\mathrm{HCl}$ buffer upon addition of DNA. [Co] $=0.5 \mu \mathrm{M}$, [DNA] $=0-100 \mu \mathrm{M}$. Arrow shows the absorbance changing upon the increase of DNA concentration. The inner plot of [DNA]/( $\left.\varepsilon_{\mathrm{a}}-\varepsilon_{\mathrm{f}}\right)$ versus [DNA] for the titration of DNA with Co(III) complex.

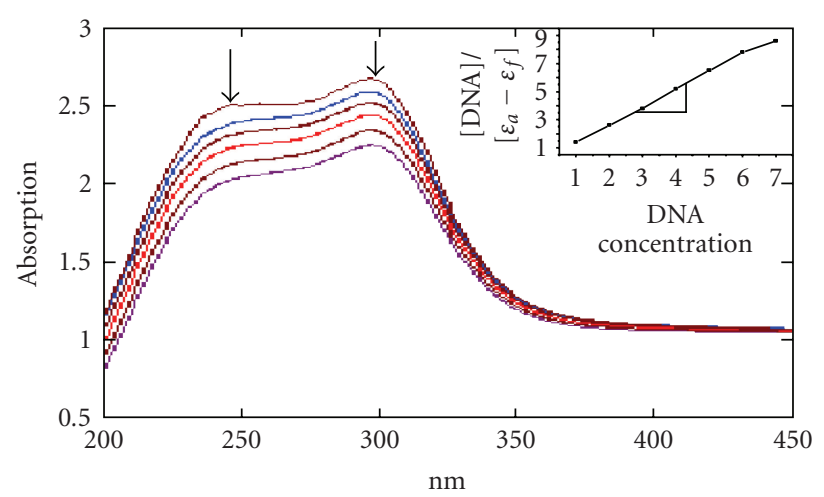

FIgURE 4: Absorption spectra of complex (2) in Tris-HCl buffer upon addition of DNA. [Ni] $=0.5 \mu \mathrm{M}$, [DNA] $=0-100 \mu \mathrm{M}$. Arrow shows the absorbance changing upon the increase of DNA concentration. The inner plot of [DNA] $/\left(\varepsilon_{\mathrm{a}}-\varepsilon_{\mathrm{f}}\right)$ versus [DNA] for the titration of DNA with $\mathrm{Ni}(\mathrm{II})$ complex.

photophysical probes provided necessary, but not sufficient, clues to support a binding model. Hydrodynamic measurements that were sensitive to leangth change (i.e., viscosity and sedimentation) were regarded as the least ambiguous and the most critical tests of binding mode in solution in the absence of crystallographic structural data [26, 27]. A classical intercalation model usually resulted in lengthening the DNA helix, as base pairs were separated to accommodate the binding ligand leading to the increase of DNA viscosity. As seen in Figure 5, the viscosity of DNA increased as increasing the ratio of both $\mathrm{Co}(\mathrm{III})$ and $\mathrm{Ni}$ (II) complexes to DNA. This result further suggested an intercalative binding mode of the complex with DNA and also paralled to the above spectroscopic results, such as hyposhromism and bathochromism of complexes in the presence of DNA.

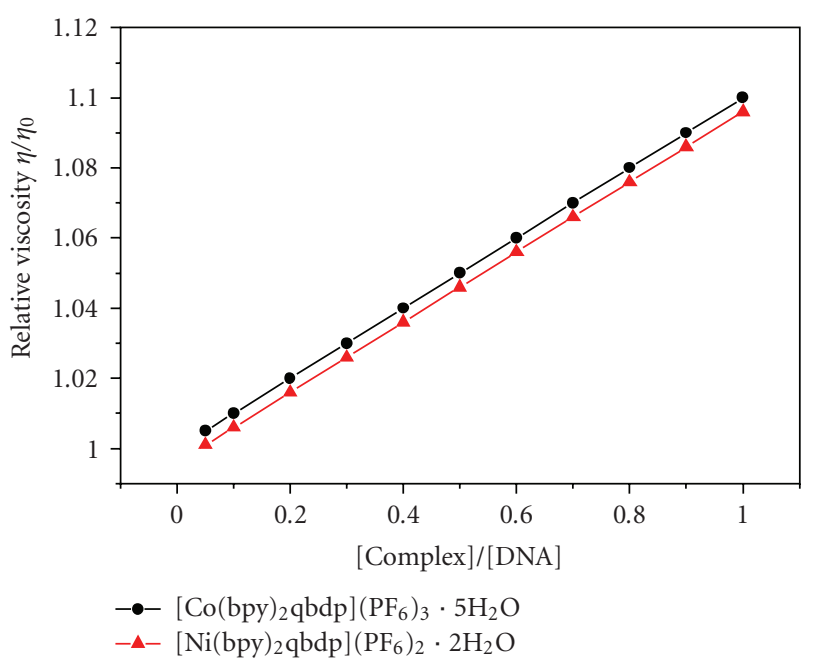

FIGURE 5: Plot of relative viscosity versus [complex]/[DNA] effect of $\left[\mathrm{Co}(\mathrm{bpy})_{2}(\mathrm{qbdp})\right]^{3+}$ and $\left[\mathrm{NI}(\mathrm{bpy})_{2}(\mathrm{qbdp})\right]^{2+}$ on the viscosity of CT-DNA at $25( \pm 0.1)^{\circ} \mathrm{C}$. $\left[\mathrm{Co}(\mathrm{bpy})_{2}(\mathrm{qbdp})\right]^{3+}=0-100 \mu \mathrm{M}$, $\left[\mathrm{NI}(\mathrm{bpy})_{2}(\mathrm{qbdp})\right]^{2+}=0-100 \mu \mathrm{M},[\mathrm{DNA}]=50 \mu \mathrm{M}$.

\subsubsection{Thermal denaturation studies}

The DNA thermal melting is a measure of the stability of the DNA double helix with temperature; an increase in the thermal melting temperature $\left(T_{\mathrm{m}}\right)$ indicates an interaction between DNA and the metal complex. In the present case, thermal melting studies were carried out at DNA to complex concentration ratios of 25 and $T_{\mathrm{m}}$ and $\sigma_{T}$ (the temperature range between which $10 \%$ and $90 \%$ of the absorption increase occurred) values were determined by monitoring the absorbance of DNA at $260 \mathrm{~nm}$ as a function of temperature. As shown in Figure 6, the $T_{\mathrm{m}}$ of DNA in the absence of any added drug was found to be $60 \pm 1^{\circ} \mathrm{C}$, under our experimental conditions. Under the same set of conditions, the presence of complexes (1) and (2) increased the $T_{\mathrm{m}}$ by 4 and $2^{\circ} \mathrm{C}$, respectively, and the values are given in Table 1 .

\subsubsection{Cleavage studies by chemical oxidation}

The oxidative DNA cleavage activity of the complexes was studied by gel electrophoresis using super coiled (SC) pUC19 DNA $(0.5 \mu \mathrm{g})$ in Tris- $\mathrm{HCl}$ buffer $(\mathrm{pH}, 7.2)$. Both complexes exhibited nuclease activity (Figure 7, lanes 3-4). Control experiment using DNA alone does not show any apparent cleavage (lane 1). At the concentration for $30 \mu \mathrm{M}$ and $40 \mu \mathrm{M}$, the complex (1) is able to convert $36 \%$ and $71 \%$ of the initial SC (Form I) to NC (nicked circular) (Form II), respectively (lanes 3 and 4 ). Whereas, the complex (2) is able to convert $66 \%$ of the initial SC (Form I) to NC (Form II) at the concentration of $20 \mu \mathrm{M}$ (lane 5). From these results, we infer that the complex (1) shows more cleavage activity than the complex (2). However, the nature of reactive intermediates involved in the DNA cleavage by the complexes has not been clear yet. 


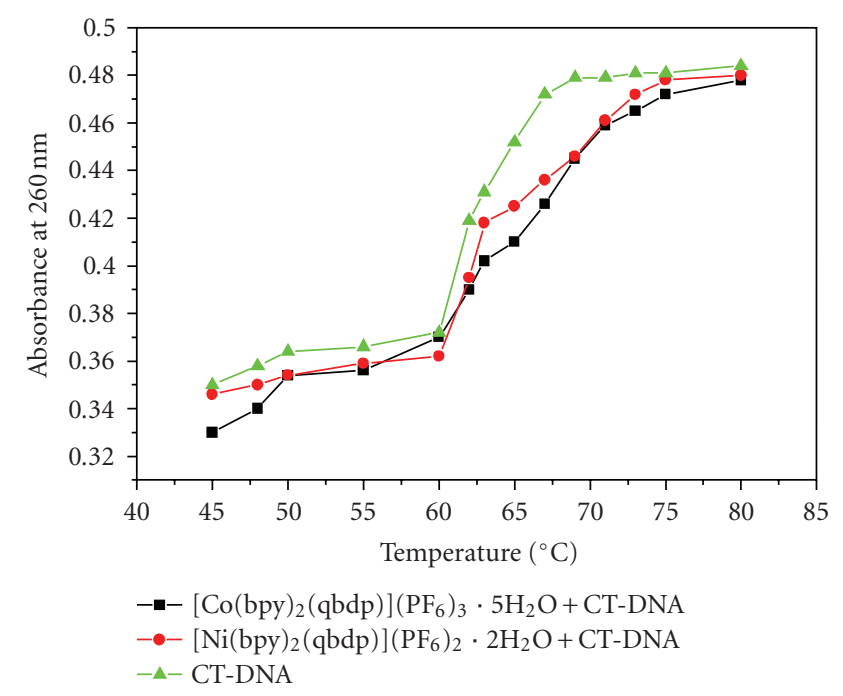

FIGURE 6: Melting curves of CT-DNA in the absence and presence of complexes.

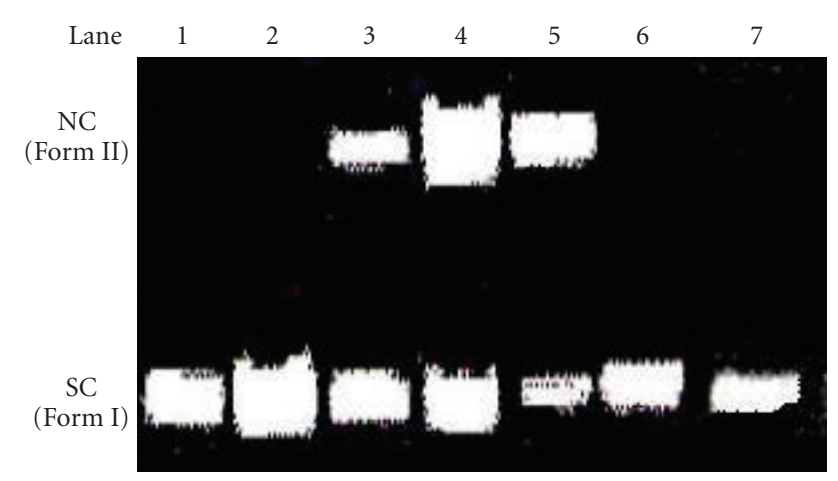

Figure 7: Cleavage of supercoiled pUC19 DNA $(0.5 \mu \mathrm{g})$ by the cobalt(III) and nickel(II) complexes in a buffer containing $50 \mathrm{mM}$ Tris- $\mathrm{HCl}$ and $50 \mathrm{mM} \mathrm{NaCl}$ at $37^{\circ} \mathrm{C}$. Lane 1: DNA alone; lane 2: DNA $+20 \mu \mathrm{M}$ of complex (1); lane 3: DNA $+30 \mu \mathrm{M}$ of complex (1); lane 4: DNA $+40 \mu \mathrm{M}$ of complex (1); lane 5: DNA $+20 \mu \mathrm{M}$ of complex (2); lane 6: DNA $+30 \mu \mathrm{M}$ of complex (2); lane 7: DNA $+40 \mu \mathrm{M}$ of complex (2). Forms I and II are supercoiled, nicked circular DNA, respectively.

\subsection{DNA photocleavage}

The photo-induced DNA cleavage activity of the complexes was studied by gel electrophoresis using supercoiled (SC) pUC19 DNA $(0.5 \mu \mathrm{g})$ in Tris-HCl buffer $(\mathrm{pH}, 7.2)$. Selected DNA cleavage data are given in Table 2 , and the gel diagrams are shown in Figure 8. The complex (1) $(30 \mu \mathrm{M}$ in $18 \mu \mathrm{L}$ volume) shows $66 \%$ cleavage of the SC DNA, whereas complex (2) $(20 \mu \mathrm{M}$ in $18 \mu \mathrm{L}$ volume) shows $37 \%$ of cleavage on 1 hour exposure at $365 \mathrm{~nm}$. Control experiments using qbdp ligand alone do not show any significant cleavage of SC DNA even on long exposure time. The results indicate the important role of metal in these photo-induced DNA cleavage reactions. The complexes show the presence of charge-

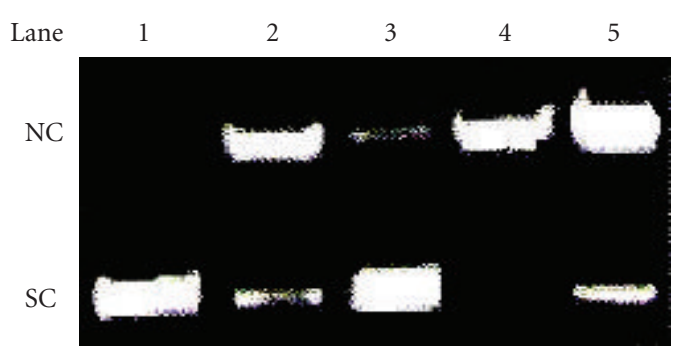

(a)

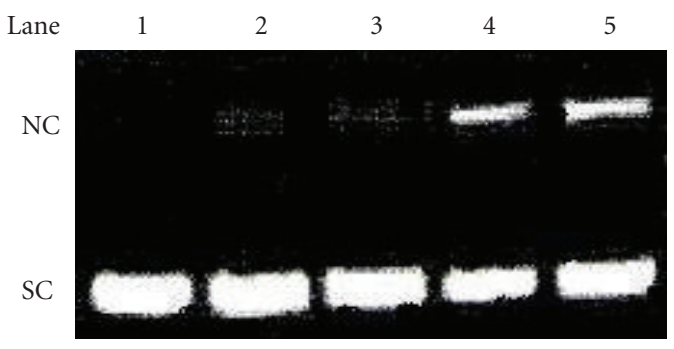

(b)

Figure 8: (a) Gel electrophoresis diagram of the control experiments using SC DNA $(0.5 \mu \mathrm{g}),(1)(30 \mu \mathrm{M})$, and other additives at $365 \mathrm{~nm}$ for an exposure time of 1 hour. Lane 1: DNA control; lane 2: DNA + DMSO $(4 \mu \mathrm{L})+(1)$; lane 3: DNA + $\mathrm{NaN}_{3}(38 \mu \mathrm{M})+$ (1); lane 4: DNA $+\mathrm{D}_{2} \mathrm{O}(14 \mu \mathrm{L})+(1)$; lane 5: DNA + (1). (b) Gel electrophoresis diagram of the control experiments using SC DNA $(0.5 \mu \mathrm{g}),(2)(30 \mu \mathrm{M})$, and other additives at $365 \mathrm{~nm}$ for an exposure time of 1 hour. Lane 1: DNA control; lane 2: DNA + DMSO $(4 \mu \mathrm{L})+$ (2); lane 3: DNA $+\mathrm{NaN}_{3}(38 \mu \mathrm{M})+(2)$; lane 4: DNA $+\mathrm{D}_{2} \mathrm{O}(14 \mu \mathrm{L})$ $+(2)$; lane 5: DNA + (2).

transfer band near $400 \mathrm{~nm}$. It is likely that the photocleavage at $365 \mathrm{~nm}$ involves photoexcitation of the charge-transfer band leading to the formation of an excited singlet state that through the triplet state activates molecular oxygen to form reactive singlet oxygen species. To test the possibility that photoinduced cleavage involves the formation of singlet oxygen, which is known to react with guanine residues at nuetral $\mathrm{pH}$, the cleavage was tested in the presence of $\mathrm{D}_{2} \mathrm{O}$. Singlet oxygen would be expected to induce more strand scission in $\mathrm{D}_{2} \mathrm{O}$ than in $\mathrm{H}_{2} \mathrm{O}$ due to its longer lifetime in the former solvent [28-31]. Control experiments show that the singlet oxygen quencher sodium azide significantly inhibits the cleavage reaction, while the hydroxyl radical scavenger DMSO has no apparent effect on the cleavage process. The formation of singlet oxygen is further supported by the enhancement of the percentage of SC DNA cleavage in $\mathrm{D}_{2} \mathrm{O}$ solvent. From the above results, we conclude that in the photocleavage activity of complexes (1) and (2) at $365 \mathrm{~nm}$, complex (1) shows significantly higher cleavage activity than complex (2) based on its DNA binding propensity.

\section{CONCLUSION}

The new mixed ligand cobalt(III) and nickel(II) complexes have been synthesized and characterized. The DNA binding 
TABLE 2: Selected DNA (SC pUC19 DNA, $0.5 \mu \mathrm{g}$ ) cleavage data of complexes (1) and (2) in Tris-buffer (pH 7.2), Form I and Form II are SC and NC forms of DNA, respectively.

\begin{tabular}{|c|c|c|c|c|c|}
\hline Reaction condition & $\lambda(\mathrm{nm})$ & $t(\mathrm{~h})$ & [Complex] $(\mu \mathrm{M})$ & Form I (\%) & Form II (\%) \\
\hline DNA control & 365 & 1.0 & - & 93 & 7 \\
\hline $\mathrm{DNA}+(\mathbf{1})$ & 365 & 1.0 & 30 & 34 & 66 \\
\hline DNA control & 365 & 1.0 & - & 98 & 2 \\
\hline $\mathrm{DNA}+(2)$ & 365 & 1.0 & 20 & 63 & 37 \\
\hline $\mathrm{DNA}+\mathrm{D}_{2} \mathrm{O}(14 \mu \mathrm{L})+(\mathbf{1})$ & 365 & 1.0 & 30 & 10 & 90 \\
\hline $\mathrm{DNA}+\mathrm{D}_{2} \mathrm{O}(14 \mu \mathrm{L})+(2)$ & 365 & 1.0 & 20 & 89 & 11 \\
\hline $\mathrm{DNA}+\mathrm{DMSO}(4 \mu \mathrm{L})+(\mathbf{1})$ & 365 & 1.0 & 30 & 29 & 71 \\
\hline $\mathrm{DNA}+\mathrm{DMSO}(4 \mu \mathrm{L})+(2)$ & 365 & 1.0 & 20 & 72 & 28 \\
\hline $\mathrm{DNA}+\mathrm{NaN}_{3}(38 \mu \mathrm{M})+(\mathbf{1})$ & 365 & 1.0 & 30 & 89 & 11 \\
\hline $\mathrm{DNA}+\mathrm{NaN}_{3}(38 \mu \mathrm{M})+(2)$ & 365 & 1.0 & 20 & 90 & 10 \\
\hline
\end{tabular}

$\lambda$ : excitation wavelength.

$T$ : exposure time.

properties of these two complexes were studied by using absorption spectra, viscosity, and thermal denaturation experiments. The results show that the complexes were interacting with the CT-DNA. We also carried out the DNA cleavage by oxidative as well as photo-irradiations. The cleavage study results show that the $\mathrm{Co}$ (III) complex is more nuclease than the $\mathrm{Ni}(\mathrm{II})$ complex.

\section{REFERENCES}

[1] R. E. Holmlin, P. J. Dandliker, and J. K. Barton, "Charge transfer through the DNA base stack," Angewandte Chemie (International Edition in English), vol. 36, no. 24, pp. 2714-2730, 1997.

[2] S. Arounaguiri, D. Eshwaramoorthy, A. Ashokkumar, A. Dattagupta, and B. G. Maiya, "Cobalt(III), nickel(II) and ruthenium(II) complexes of 1, 10-phenanthroline family of ligands: DNA binding and photocleavage studies," Proceedings of the Indian Academy of Sciences: Chemical Sciences, vol. 112, no. 1 , pp. 1-17, 2000

[3] S. Leininger, B. Olenyuk, and P. J. Stang, "Self-assembly of discrete cyclic nanostructures mediated by transition metals," Chemical Reviews, vol. 100, no. 3, pp. 853-907, 2000.

[4] S. Feng and R. Xu, "New materials in hydrothermal synthesis," Accounts of Chemical Research, vol. 34, no. 3, pp. 239-247, 2001.

[5] M. Yuan, Y. Li, E. Wang, et al., "Hydrothermal synthesis and crystal structure of a hybrid material based on $\left[\mathrm{Co}_{4}(\text { phen })_{8}\left(\mathrm{H}_{2} \mathrm{O}\right)_{2}\left(\mathrm{HPO}_{3}\right)_{2}\right]^{4+}$ and a highly reduced polyoxoanion," Journal of the Chemical Society, Dalton Transactions, no. 14, pp. 2916-2920, 2002.

[6] Y. Lu, E. Wang, M. Yuan, et al., "Hydrothermal synthesis and crystal structure of a layered vanadium phosphate with a directly coordinated organonitrogen ligand: $\left[\left(\mathrm{V}_{4} \mathrm{O}_{7}\right)\left(\mathrm{HPO}_{4}\right)_{2}\left(2,2^{\prime}-\text { bipy }\right)_{2}\right]$," Journal of the Chemical Society, Dalton Transactions, no. 15, pp. 3029-3031, 2002.

[7] E. Lamour, S. Routier, J.-L. Bernier, J.-P. Catteau, C. Bailly, and H. J. Vezin, "Oxidation of $\mathrm{Cu}^{\mathrm{II}}$ to $\mathrm{Cu}$, free radical production and DNA cleavage by hydroxy-salen-copper complexes. Isomeric effects studied by ESR and electrochemistry," Journal of American Chemical Society, vol. 121, no. 9, pp. 1862-1869, 1999.
[8] A. K.-D. Mesmaeker, J.-P. Lecomte, and J. M. Kelly, "Photoreactions of metal complexes with DNA, especially those involving a primary photo-electron transfer," in Electron Transfer II, vol. 177 of Topics in Current Chemistry, pp. 25-76, Springer, Berlin, Germany, 1996.

[9] B. Norden, P. Lincoln, B. Akerman, and E. Tuite, "DNA interactions with substitution-inert transition metal ion complexes," in Metal Ions in Biological Systems: Probing of Nucleic Acids by Metal Ion Complexes of Small Molecules, A. Sigel and H. Sigel, Eds., vol. 33, pp. 177-252, Marcel Dekker, New York, NY, USA, 1996.

[10] D. S. Sigman, A. Mazumder, and D. M. Perrin, "Chemical nucleases," Chemical Reviews, vol. 93, no. 6, pp. 2295-2316, 1993.

[11] T. Ghosh, B. G. Maiya, A. Samanta, et al., "Mixed-ligand complexes of ruthenium(II) containing new photoactive or electroactive ligands: synthesis, spectral characterization and DNA interactions," Journal of Biological Inorganic Chemistry, vol. 10, no. 5, pp. 496-508, 2005.

[12] N. J. Turro, J. K. Barton, and D. A. Tomalia, "Molecular recognition and chemistry in restricted reaction spaces. Photophysics and photoinduced electron transfer on the surfaces of micelles, dendrimers, and DNA," Accounts of Chemical Research, vol. 24, no. 11, pp. 332-340, 1991.

[13] F. Q. Liu, Q. X. Wang, K. Jiao, F. F. Jian, G. Y. Liu, and R. X. Li, "Synthesis, crystal structure, and DNA-binding properties of a new copper (II) complex containing mixed-ligands of 2, 2' bipyridine and $p$-methylbenzoate," Inorganica Chimica Acta, vol. 359, no. 5, pp. 1524-1530, 2006.

[14] T. D. Tullis, Metal-DNA Chemistry, ACS Symposium Series no. 402, American Chemical Society, Washington, DC, USA, 1989.

[15] J. K. Barton, "Metals and DNA: molecular left-handed complements," Science, vol. 233, no. 4765, pp. 727-734, 1986.

[16] S. Arounaguiri and B. G. Maiya, "Dipyridophenazine complexes of cobalt(III) and nickel(II): DNA-binding and photocleavage studies," Inorganic Chemistry, vol. 35, no. 14, pp. 4267-4270, 1996.

[17] S. Arounaguiri, A. Dattagupta, and B. G. Maiya, "Redoxactivated luminescence and light-induced nuclease activity of a new mixed-ligand ruthenium(II) complex," Proceedings of the Indian Academy of Sciences: Chemical Sciences, vol. 109, no. 2, pp. 155-158, 1997. 
[18] S. Arounaguiri and B. G. Maiya, “"Electro-photo switch” and "molecular light switch" devices based on ruthenium(II) complexes of modified dipyridophenazine ligands: modulation of the photochemical function through ligand design," Inorganic Chemistry, vol. 38, no. 5, pp. 842-843, 1999.

[19] A. A. Vlček, "Preparation of $\mathrm{Co}(\text { dipy })_{2} \mathrm{X}_{2}^{+}$complexes $\left(\mathrm{X}^{-}=\right.$ $\mathrm{C} 1, \mathrm{Br}^{-}, \mathrm{I}^{-}, \mathrm{NO}_{2}^{-}$) by controlled oxidative processes," Journal of Inorganic Chemistry, vol. 6, no. 7, pp. 1425-1427, 1967.

[20] C. M. Harris and E. D. McKenzie, "Nitrogenous chelate complexes of transition metals-III bis-chelate copmlexes of nickel(II) with 1.10-phenanthroline, 2, 2' -bipyridal and analogus ligands," Journal of Inorganic Nuclear Chemistry, vol. 29, no. 4, pp. 1047-1068, 1967.

[21] M. E. Reichmann, S. A. Rice, C. A. Thomas, and P. Doty, "A furhter examination of the molecular weight and size of deoxy pentose nucleic acid," Journal of American Chemical Society, vol. 76, pp. 3047-3053, 1954.

[22] A. Wolfe, G. H. Shimer Jr., and T. Meehan, "Polycyclic aromatic hydrocarbons physically intercalate into duplex regions of denatured DNA," Biochemistry, vol. 26, no. 20, pp. 63926396, 1987.

[23] A. Raja, V. Rajendiran, P. U. Maheswari, et al., "Copper(II) complexes of tridentate pyridylmethylethylenediamines: role of ligand steric hindrance on DNA binding and cleavage," Journal of Inorganic Biochemistry, vol. 99, no. 8, pp. 17171732, 2005.

[24] H. Zhang, C.-S. Liu, X.-H. Bu, and M. Yang, "Synthesis, crystal structure, cytotoxic activity and DNA-binding properties of the copper (II) and zinc (II) complexes with 1-[3-(2pyridyl)pyrazol-1-ylmethyl] naphthalene," Journal of Inorganic Biochemistry, vol. 99, no. 5, pp. 1119-1125, 2005.

[25] A. Frodl, D. Herebian, and W. S. Sheldrick, "Coligand tuning of the DNA binding properties of bioorgano-metallic ( $\eta 6$-arene)ruthenium(II) complexes of the type [ $\eta 6$-arene)$\mathrm{Ru}(\text { amino acid) }(\mathrm{dppz})]^{n+}\left(\mathrm{dppz}=\operatorname{dipyrido}\left[3,2-a: 2^{\prime}, 3^{\prime}-\right.\right.$ c]phenazine), $n=1-3$," Journal of the Chemical Society, Dalton Transactions, no. 19, pp. 3664-3673, 2002.

[26] S. Satyanarayana, J. C. Dabrowiak, and J. B. Chaires, "Tris(phenanthroline)ruthenium(II) enantiomer interactions with DNA: mode and specificity of binding," Biochemistry, vol. 32, no. 10, pp. 2573-2584, 1993.

[27] S. Satyanarayana, J. C. Dabrowiak, and J. B. Chaires, "Neither $\Delta$ - nor $\Lambda$-tris(phenanthroline)ruthenium(II) binds to DNA by classical intercalation," Biochemistry, vol. 31, no. 39, pp. 93199324, 1992.

[28] J. D. Spikes, "Photosensitization," in The Science of Photobiology, K. C. Smith, Ed., pp. 87-112, Plenum, New York, NY, USA, 1977.

[29] P. C. Lee and M. A. Rodgers, "Laser flash photokinetic studies of rose bengal sensitized photodynamic interactions of nucleotides and DNA," Photochemistry and Photobiology, vol. 45, no. 1, pp. 79-86, 1986.

[30] A. U. Khan, "Singlet molecular oxygen. A new kind of oxygen," Journal of Physical Chemistry, vol. 80, no. 20, pp. 2219-2228, 1976.

[31] S. K. Chatopadhyay, C. V. Kumar, and P. K. Das, "Laser flash photolytic determination of triplet yields via singlet oxygen generation," Journal of Photochemistry, vol. 24, no. 1, pp. 1-9, 1984. 


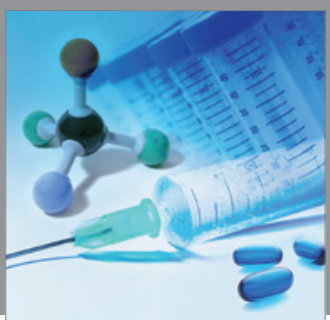

International Journal of

Medicinal Chemistry

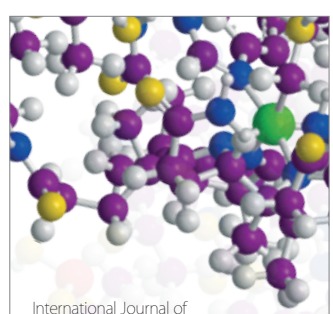

Carbohydrate Chemistry

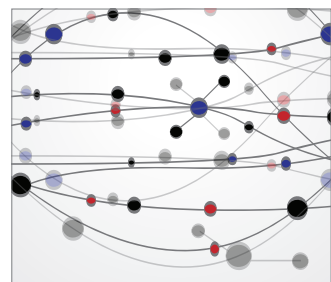

The Scientific World Journal
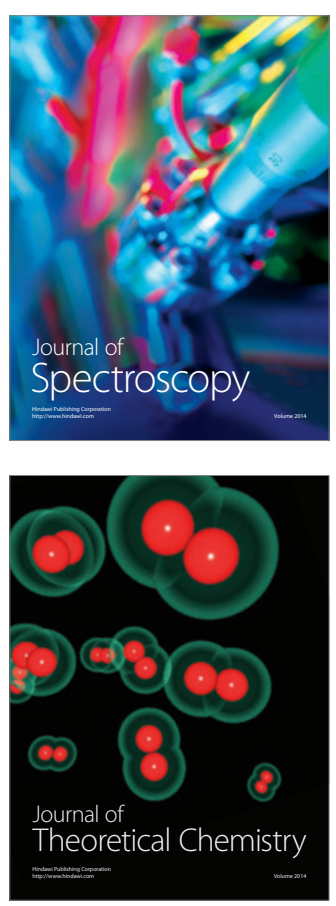
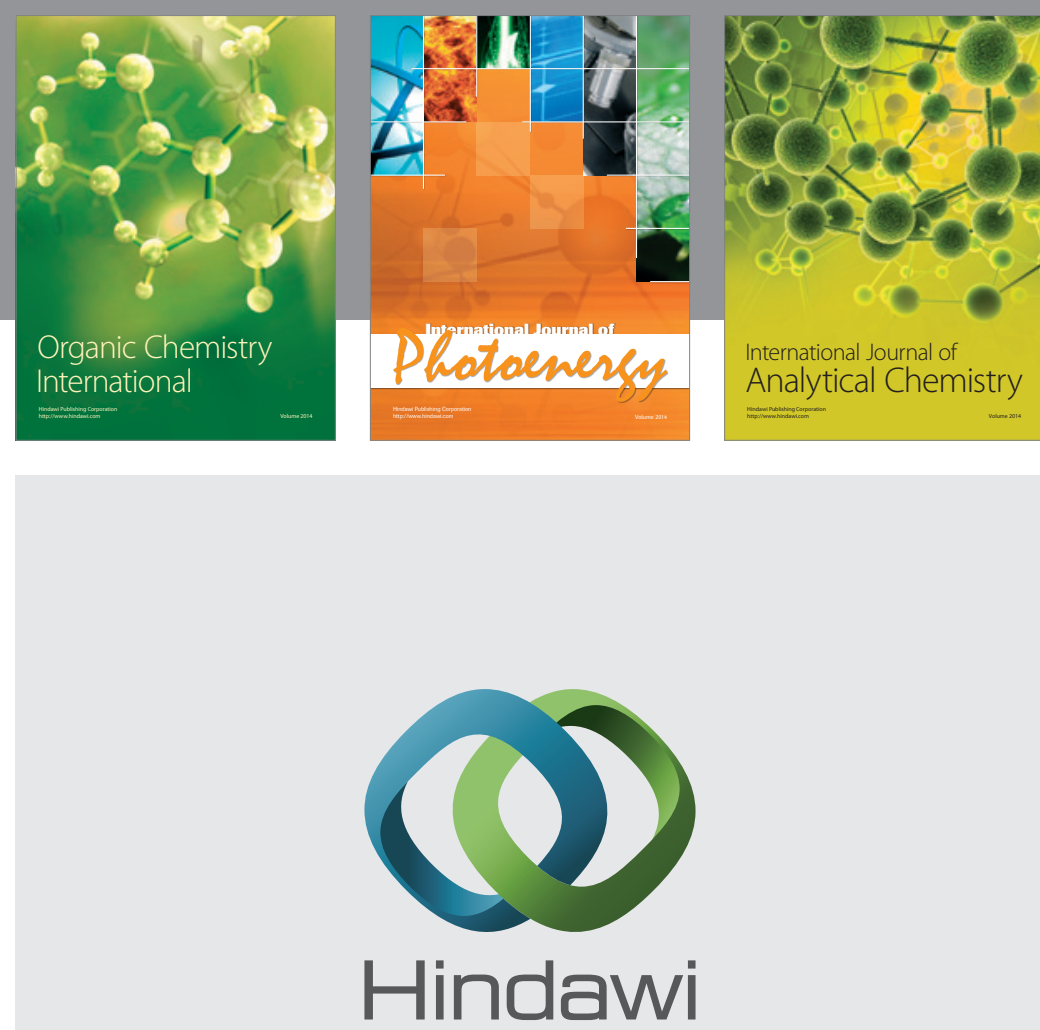

Submit your manuscripts at

http://www.hindawi.com
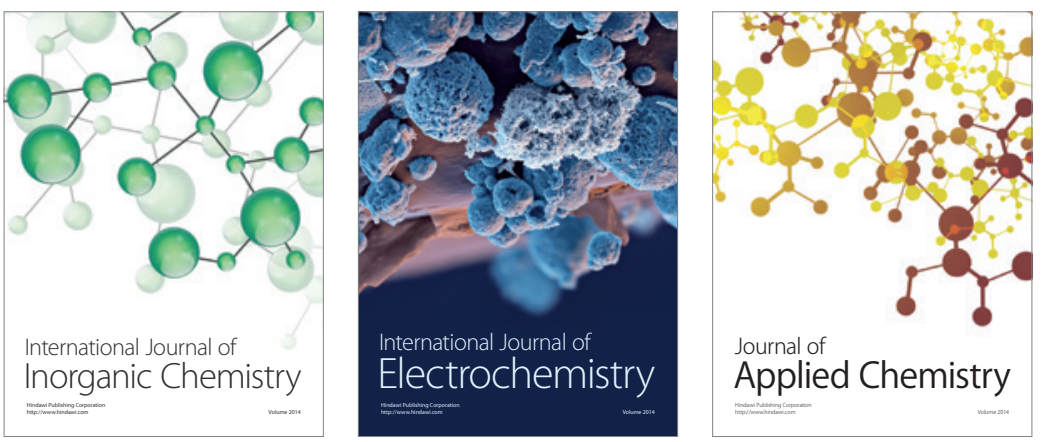

Journal of

Applied Chemistry
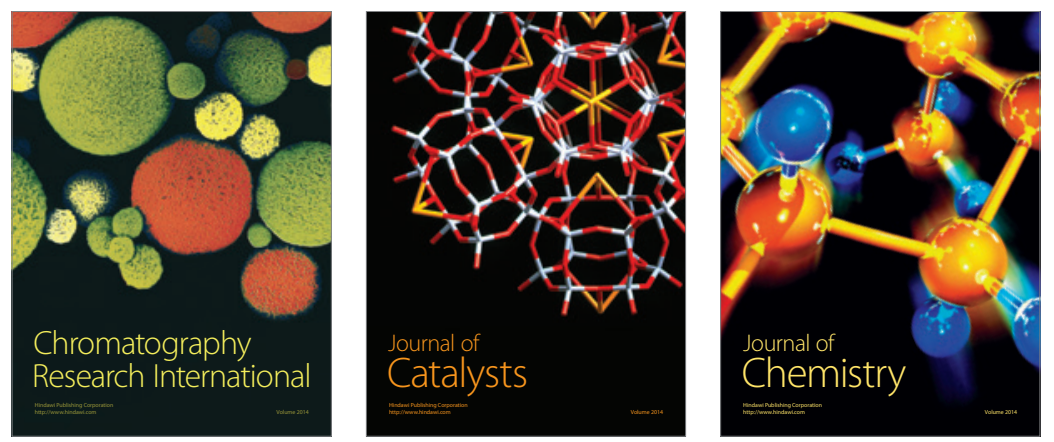
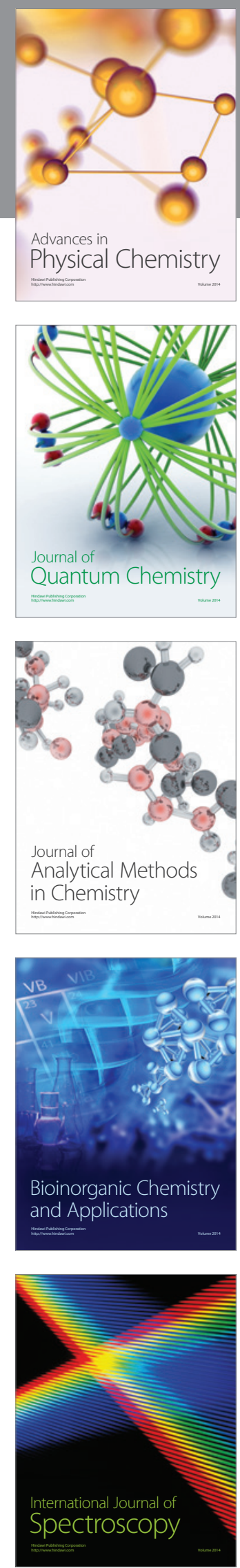